University at Buffalo School of Law

Digital Commons @ University at Buffalo School of Law

\title{
Freedom of Contract and Freedom of Person: A Brief History of "Involuntary Servitude" in American Fundamental Law
}

\author{
Robert J. Steinfeld \\ University at Buffalo School of Law, steinfel@buffalo.edu
}

Follow this and additional works at: https://digitalcommons.law.buffalo.edu/book_sections

Part of the Labor and Employment Law Commons, and the Legal History Commons

\section{Recommended Citation}

Robert J. Steinfeld, Freedom of Contract and Freedom of Person: A Brief History of "Involuntary Servitude" in American Fundamental Law in Republicanism and Liberalism in America and the German States, 1750-1850 281 (Jürgen Heideking, James A. Henretta \& Peter Becker, eds., Cambridge University Press 2001)

This material has been published in Republicanism and Liberalism in America and the German States, 1750-1850 edited by Jürgen Heideking, James A. Henretta \& Peter Becker. This version is free to view and download for personal use only. Not for re-distribution, re-sale or use in derivative works. (C) The German Historical Institute 2004.

\section{IN}

This Book is brought to you for free and open access by the Faculty Scholarship at Digital Commons @ University at Buffalo School of Law. It has been accepted for inclusion in Contributions to Books by an authorized administrator of Digital Commons @ University at Buffalo School of Law. For more information, please contact lawscholar@buffalo.edu. 


\title{
Freedom of Contract and Freedom of Person: A Brief History of "Involuntary Servitude" in American Fundamental Law
}

\author{
ROBERT J. STEINFELD
}

Liberal ideas are normally taken to have played an important role in the development of free markets, and of free labor based on contract in those markets. A closer look at labor regimes in the nineteenth century, however, reveals that liberal commitments to freedom did not straightforwardly produce what we today would think of as free labor. Just as often they produced a form of coerced contractual labor. And this was quite simply because liberal commitments to freedom embraced a basic conflict between freedom of contract and freedom of person.

To the extent that one possessed absolute freedom of contract, one would have been free to contract away one's personal liberty. One would have been free to contract into slavery or bind one's labor irrevocably for long periods of time. To the extent that the state found it desirable to prevent this result, it could only do so by imposing limitations on the freedom of contract in the interest of preserving the freedom of persons.

Modern free labor is the result of just such a choice to restrict freedom of contract. Before this basic issue within liberalism was finally resolved in favor of freedom of person and against freedom of contract, many of the first market regimes based on free contract produced coerced contractual labor rather than free labor. In the first flourishing of free contract in the nineteenth century, lawmakers in many different countries seem to have believed that labor markets based on promises could only function properly if contracts could be rigorously enforced against workers. As a result they often gave employers harsh remedies for contract breach so that they could compel workers to perform their agreements. 
In effect, these contract regimes allowed workers to bind their labor irrevocably for a time. They represented the expression of a kind of freedom of contract, the freedom to contract away part of one's freedom for a time. Only when this contractual freedom was limited by circumscribing the kinds of contract remedies employers enjoyed at law, or were permitted to induce workers to agree to in labor contracts, was modern free labor created. Modern free labor was not the product of liberal ideas as they were manifested in free markets but the product of a difficult political and moral resolution of fundamental dilemmas within liberalism itself.

Freedom of trade (Gewerbefreiheit) was introduced into Prussia by the Industrial Law (Gewerbeordnung) of $1845 .{ }^{1}$ As part of this liberal, free-market reform, the relationships between masters and their journeymen in the artisanal sector, and factory workers and their employers in the expanding industrial sector, were made a matter of free contract. ${ }^{2}$ For breach of these freely negotiated contracts, however, factory workers, journeymen, and other wage workers were subject to penal sanctions, including imprisonment. The law declared that "journeymen, helpers, and factory workers, who leave work without permission and without legal justification, or are guilty of shirking, or gross disobedience or insistent obstinacy, are to be punished by a fine of up to twenty thalers or imprisonment for up to fourteen days."3 Penal sanctions for breach of contract by factory workers were later eliminated by the Industrial Law of $1869 .^{4}$

It is interesting that Prussia was far from being alone in nineteenthcentury Europe in imposing penal sanctions on wage workers for breach of contract. In England, which possessed the most advanced economy of this period, Parliament imposed even harsher penal sanctions on English wage workers who could be imprisoned for up to three months for quitting before the expiration of their contracts, for leaving work without permission, or for disobedience. ${ }^{5}$ Between 1720 and 1843, during the same period in which free markets replaced the traditional economy, Parliament passed more than half a dozen statutes mandating penal sanctions for labor-contract breaches. ${ }^{6}$ Between 1857 and 1875 about

1 Gesetzsammlung für die Königlichen Preussischen Staaten 1845, "Gewerbeordnung," 41-78 (hereafter PGS, 1845). Freedom of trade, however, was repealed four years later in 1849 , and not reestablished in Prussia until the Industrial Law of 1869 , enacted by the North German Confederation.

2 PGS, 1845, "Gewerbeordnung," \$S 134, 145. 3 PGS, 1845, "Gewerbeordnung," \$ 184.

4 Bundesgesetzblatt des Norddeutschen Bundes, 1869, "Gewerbeordnung," no. 26, 245-82, \ 154.

5 See, e.g., 4 Geo. IV., c. 34, \ III (1823). Until the last quarter of the nineteenth century it was common for English wage workers to serve either under contracts for a term or under contracts terminable only after some period of notice had been given. Employment at will was fairly unusual among skilled workers of the period.

6 Sidney Webb and Beatrice Webb, The History of Trade Unionism (London, 1956), 250-1n2. 
10,000 workers per year were proceeded against in England for violating their labor agreements. ${ }^{7}$

In the twentieth century the criminal enforcement of labor contracts has come to be viewed as rendering such labor "coerced" or "involuntary." During the nineteenth century, however, that was far from being the view of many Europeans; from their standpoint free markets required reliable contract enforcement. Without reliable contract enforcement large-scale markets would not have been feasible. ${ }^{8}$ As one historian recently observed,

it was not until the eighteenth century, in Western Europe, England, and North America, that societies first appeared whose economic systems depended on the expectation that most people, most of the time, were sufficiently conscience ridden (and certain of retribution) that they could be trusted to keep their promises.... Only to the extent that [the] norm [of promise keeping] prevails can economic affairs be based on nothing more authoritative than the obligation arising out of promises.

Both the growing force of the norm of promise keeping and its synchronization with the spread of market relations are clearly inscribed in the history of the law of contract.... For the first time the law strained to make promisors generally liable for whatever expectations their promises created. Never before had promises counted for so much in human affairs, and never before had the penalties for being short-willed and unreliable been so severe. ${ }^{9}$

Nineteenth-century European legal rules mandating penal sanctions for breach of labor contracts must be seen as part of the process by which freer markets were created. Large-scale free labor markets simply could not function properly unless labor contracts could be reliably enforced. But labor agreements, it was widely believed at the time, could not be reliably enforced against largely propertyless workers by means of monetary damages. ${ }^{10}$ Penal sanctions represented, under the circumstances, nothing more than a remedy for breach of contract in situations where monetary damages could not be relied on. Such a remedy was thought to be an essential aspect of free contract in labor markets.

Not very much has been written explaining the abolition in 1869 of penal sanctions for breach of contract by factory workers in Germany, but in England the process has been described in detail. Organized labor

7 Judicial Statistics, England and Wales, 1857-1875, 19 vols. (London, 1858-76); see also Daphne Simon, "Master and Servant," in John Saville, ed., Democracy and the Labour Movement (London, 1954), 186n2.

8 Douglass C. North, Institutions, Institutional Change, and Economic Performance (Cambridge, 1990), 33-5.

9 Thomas Haskell, “Capitalism and the Humanitarian Sensibility, Part 2," American Historical Review 90 (1985): 553-5.

10 See, e.g., James Edward Davis, The Master and Servant Act, 1867 (London, 1868), 7. 
mounted a long campaign beginning in the early 1860 s to have penal sanctions repealed. In 1875 Parliament finally responded to the growing power of labor by repealing the statutes. In England, labor prevailed in this campaign not only because of its growing electoral influence but also because its reinterpretation of penal sanctions came to be widely accepted in English culture, including English legal culture. ${ }^{11}$ From an ordinary contract remedy entirely consistent with the liberal principle of free contract, penal sanctions began to be recharacterized as a remedy inconsistent with the liberal principle of equal treatment under the law. (It was not equally available to workers for employer contract breaches.) ${ }^{12}$ Over the ensuing twenty-five years it came increasingly to be seen as a contract remedy that turned "contracts of service" into "contracts of slavery" and therefore became increasingly inconsistent with the long-standing liberal tradition that freedom of contract should not extend to contracts of slavery. ${ }^{13}$

It seems clear that many nineteenth-century Europeans drew the distinction between "free" and "coerced" labor differently than we do, but that that line began to be redrawn by the end of the nineteenth century. There is a very basic reason why the line between "voluntary free" labor and "involuntary coerced" labor has been drawn in different ways at different times. Nearly all forms of labor not performed for sheer pleasure can be characterized in either way. When we speak about most kinds of labor compulsion, we are talking about situations in which the compelled party is offered a choice between disagreeable alternatives and chooses the lesser evil.

This type of compulsion is present, for example, in both slavery and modern free wage labor. In slavery, labor normally is not elicited by directly imparting motion to a slave's limbs through overpowering physical force. It is compelled by forcing slaves to choose among very unpleasant options, for example, among death, dismemberment, torture, and endless confinement, on the one hand, or backbreaking physical labor, on the other. The labor of free wage workers is similarly elicited by offering workers a choice, for example, between life on an inadequate welfare stipend, on the one hand, or performing more or less unpleasant work for wages, on the other. In the case of both the slave and the free worker, the parties may be said to have been coerced into performing the labor or to have freely chosen the lesser evil. Either characterization is applicable. This is why some choices

11 The Second Reform Act, which was passed in 1867, extended the suffrage to many town artisans.

12 Frederic Harrison, "Tracts for Trade Unionists" in Edmund Frow and Michael Katanka, eds., 1868, Year of the Unions: A Documentary Survey (New York, 1968), 141-2.

13 L. J. Fry in De Francesco v. Barnum, 45 chap., d. 430 (1890), 438. 
among evils can be characterized as voluntary decisions, whereas other choices among evils can simultaneously be characterized as coerced. Where the line is drawn from a logical standpoint is arbitrary.

Needless to say, the choices presented in slavery are much harsher than the choices normally presented in free wage labor. We may rightly say, therefore, that the degree of coercion in one form is normally much greater than it is in the other, but there are no legal grounds for saying that the performance of labor in one case is coerced, whereas in the other it is voluntary. As a matter of logic we have to say either that both are involuntary to different degrees or that both involve the free choice of a lesser evil.

The judgment about where to draw the line separating voluntary from involuntary labor turns out not to be a judgment about where coercion begins or ends in labor relations, but rather a judgment about what kinds of hard choices we will allow some individuals to force other individuals to make as the latter decide whether to enter or leave a labor relation, and which kinds of hard choices we will not permit.

Judgments like these are equally involved in the modern definition of free labor and are inscribed in modern contract and constitutional law. The remedy of monetary damages for labor-contract breaches (which is permitted under modern law) will coerce workers into satisfying their labor agreements under certain circumstances. "[A]ny legal liability for breach of contract," Justice Oliver Wendell Holmes wrote, "is a disagreeable consequence which tends to make the contractor do as he said he would." "In the case of a solvent person," the legal realist Robert Hale noted, "the motive for performing might often be the desire to escape pecuniary liability [for breach of contract]. If such desire is strong enough to make him render the services stipulated in his contract, then the law does compel performance and enforce the labor." ${ }^{15}$

It is only by ignoring the coercive effects of various pecuniary remedies for breach of contract that the modern definition (and law) of free labor is arrived at, in the same way that many nineteenth-century Europeans ignored the coercive effects of penal sanctions for breach of contract in their definition of free labor. The modern definition (and law) of free labor also ignores a range of other, so-called "economic" pressures that may compel workers to enter employment, to submit to discipline during employment, and to remain in employment.

15 Robert L. Hale, Freedom Through Law: Public Control of Private Governing Power (New York, 1952), 191. 
John Stuart Mill, writing a decade after the English Poor Law implemented a policy of less eligibility in the reforms of 1832, noted that free wage workers could be expected to enter employment only in situations in which the main alternative to employment was kept more disagreeable than employment itself.

If the condition of a person receiving [poor] relief is made as eligible as that of the labourer who supports himself by his own exertions ... [it] would require as its supplement an organized system of compulsion, for governing and setting [people] to work.... But if, consistently with guaranteeing all persons against absolute want, the condition of those who are supported by legal charity can be kept considerably less desirable than the condition of those who find support for themselves, none but beneficial consequences can arise. ${ }^{16}$

As in Europe, the modern American constitutional definition of free labor was only arrived at after a long struggle over the precise line that should separate the types of hard choices that would "coerce" the labor of workers who confronted them from the types of hard choices that left workers "free" to choose labor as the lesser evil.

American fundamental law on the subject of coerced labor can be traced back to the language of the Northwest Ordinance enacted by Congress in 1787. It declared that "There shall be neither Slavery nor involuntary servitude in the [Northwest] territory otherwise than in the punishment of crimes, whereof the party shall have been duly convicted." ${ }^{\prime 7}$ The ordinance applied to an area that encompasses the present-day states of Illinois, Indiana, Michigan, Ohio, and Wisconsin. But the language of the ordinance was later incorporated into the Thirteenth Amendment to the United States Constitution, which abolished slavery and involuntary servitude throughout the nation.

It is primarily to the interpretation of the term involuntary servitude, first in the ordinance and later in the Thirteenth Amendment, that we must turn for an understanding of the changing definition of free labor in American fundamental law. As we examine these legal interpretations, however, we should keep at least two things in mind. First, adult white indentured servants were still being imported into the United States in 1787 and would continue to be imported in significant numbers until 1820, and in smaller numbers until at least 1830. It seems likely that the framers of the Northwest Ordinance would have considered these contractual arrangements to be voluntary rather than involuntary servitude, which the ordinance prohibited. 
Second, unlike the situation in England and Prussia, these imported indentured servants were the only adult white workers subject at the time to penal sanctions for labor-contract breaches. The reasons for this development are a bit of a mystery, but we do know that it is traceable to the eighteenth century. Before 1700 statutes in a number of American colonies subjected "hired" workers to penal sanctions for breaches of contract. But over the course of that century these statutes began to disappear from the colonial codes, leaving immigrant indentured servants the only white adult contractual labor still subject to penal sanctions.

It was a struggle over the legality of indentured servitude under the provisions of the Northwest Ordinance that produced the first judicial interpretations of involuntary servitude. The southern border of the Northwest Territory was shared with areas in which slavery was entrenched and legal. When settlers from these areas began to arrive in the Northwest Territory, many brought slaves with them. Others believed it would be beneficial to the new territory to allow slaves to be imported. One expedient under which slaves were held in parts of the territory was to have them sign indentures committing them to twenty, forty, or more years of service, either before they were brought into the territory or after they arrived.

When the question of the legality of black indentured servitude was brought before the high courts of two of the states carved out of the territory, it produced two very different interpretations of precisely what practices were prohibited by the ban on involuntary servitude. In Phoebe v. Jay, decided in 1828, the Illinois Supreme Court framed the issue in terms of whether a laboring agreement had been entered into "voluntarily." 18 If it had, then legal enforcement of the resulting agreement through specific performance or penal sanctions did not transform the labor from voluntary to involuntary. The labor was "voluntary" because the worker had "voluntarily" agreed to perform it. All that was involved was the enforcement of a contract entered into freely. ${ }^{19}$

Given the long history of indentured servitude in this country and the common practice of penal sanctions to enforce labor contracts in Europe, the Illinois court's view of involuntary servitude was probably quite widely shared at the time. The Illinois ruling did leave unresolved the question of how harsh the terms of a "voluntary" labor agreement would have to be before the agreement would be considered a contract of slavery and be

19 Ibid. See also, the concurring opinion of Justice Thomas in Sarah, a woman of color v. Borders, 4 Scam. 341 (Ill., 1843), 347. 
rendered illegal by the absolute prohibition against slavery contained in the ordinance. But under the Illinois ruling any state of servitude short of outright slavery apparently could be entered into in conformity with the ordinance, as long as it was done voluntarily.

The Illinois court did, however, have to face the question of precisely what circumstances would render a decision to sign an indenture "involuntary" in the first place. In Phoebe v. Jay a black woman had signed an indenture to serve her master for forty years. ${ }^{20}$ The indenture had been entered into pursuant to a statute that allowed slave masters to bring slaves into the territory but required that they bring the slave before a clerk of the court of common pleas within thirty days, "and in the presence of said clerk, the said owner or possessor shall determine and agree, to and with his or her negro or mulatto, upon the term of years which the said negro or mulatto will and shall serve his or her said owner or possessor." ${ }^{21}$ If a black person refused to sign an indenture or to perform its terms, the master was authorized under the statute to return the person to the state in which he or she had been held as a slave.

The Illinois court entertained no doubt that the decision to sign an indenture made by a black person confronted with this set of choices must represent a coerced decision rather than the free choice of a lesser evil. "I conceive that it would be an insult to common sense," Justice Lockwood wrote for the court, "to contend that the negro, under the circumstances in which [s] he was placed, had any free agency. The only choice given [her] was a choice of evils." 22 What other hard choices might coerce a person into entering a labor relation involuntarily remained to be explored.

If in Illinois the specific enforcement of a forty-year labor agreement did not render the labor involuntary so long as it had been entered into voluntarily, such was not the case in Indiana. In 1821 the Indiana high court set aside the indenture of a black woman who, the court reported, had "voluntarily bound herself to serve ... as an indented servant and housemaid for 20 years." 23 The court ruled that

while the [woman] remained in the service of the obligee without complaint, the law presumes that her service was voluntarily performed; but her application to the Circuit Court to be discharged from the custody of her master, establishes the fact that she is willing to serve no longer; and, while this state of the will appears, the law can not, by any possibility of intendment, presume that her service is voluntary... The fact then is, that the appellant is in a state of involuntary

23 The Case of Mary Clark, a woman of color, 1 Blackf.122 (Ind. 1821), 123. 
servitude; and we are bound by the Constitution, the supreme law of the land, to discharge her therefrom. ${ }^{24}$

Under the Indiana ruling, labor became involuntary servitude the moment a person wanted to leave the relationship but was prevented from doing so by a judicial decree of specific performance or by bodily seizure by an employer. Here, the legal right to withdraw from the labor relationship at any time marked the boundary between free labor and involuntary servitude. The use of the legal remedies of specific performance or penal sanction to enforce even a voluntary labor agreement turned the labor into involuntary servitude. The issue implicitly left unresolved by the Indiana decision was whether a labor contract could be enforced through any legal remedy at all consistent with the proscription of involuntary servitude.

More fundamentally, the Indiana ruling brought to the surface a fundamental problem within liberal commitments to freedom, which contained a basic, unresolvable contradiction between commitments to liberty of person and commitments to liberty of contract. Liberty of person under the rule required that one's contractual liberty be restricted, insofar as one was no longer legally entitled to alienate one's labor irrevocably by contract. $^{25}$

These opposing interpretive traditions persisted in American constitutional law throughout the nineteenth century. The United States Supreme Court, surprisingly, did not make a definitive choice between them until the twentieth century. This is not to say that both views enjoyed equal popularity in the wider culture. It is fair to say that throughout the North, labor practices and ideas conformed in the main to the view set forth by the Indiana court. With the complete disappearance of white immigrant indentured servitude in the 1830s the labor agreements of white adults were not subject to specific performance or to penal sanctions anywhere in the Northern states, with one significant exception discussed subsequently. But there were only a few court opinions inscribing this view into constitutional law. One was rendered by the Massachusetts Supreme Judicial Court in 1856.

In Parsons v. Trask, the Massachusetts Supreme Judicial Court held that a voluntary labor contract amounted to a species of servitude akin to slavery when a worker was not free to leave before its expiration and if the nature

25 On this contradiction, see Guyora Binder, "Substantive Liberty and the Legacy of the Fuller Court," unpublished manuscript in author's possession, SVI. (30.); and Frank H. Knight, Freedom \& Reform: Essays in Economics and Social Philosophy (New York, 1947; reprint, 1982), 78-9. 
of the services and the place where they were to be performed were left to be determined unilaterally by the employer. ${ }^{26}$

Even the Civil War did not lay the interpretive question definitively to rest. The Thirteenth Amendment incorporated the language of the Northwest Ordinance but did not provide clarification. In 1867 Congress adopted the Indiana and Massachusetts interpretation of the term involuntary servitude in the Anti-Peonage Act it passed that year pursuant to the Thirteenth Amendment. The peonage statute that Congress enacted in 1867 reached a labor relationship that was often entered into voluntarily. But the statute had been drafted poorly and its language was ambiguous. More fundamentally, the interpretive question had not been definitively resolved. The U.S. Army and, in certain cases, agents of the Freedmen's Bureau, for example, could still believe that they were introducing a free labor system into the South after the war even as they went about specifically enforcing the labor contracts of former slaves who came under their jurisdiction.

The U.S. Supreme Court did not directly confront the issue until 1897, when a majority of the court adopted not the Indiana and Massachusetts interpretations of "involuntary servitude" as we might have expected but rather the Illinois reading. However, the Indiana view, which was to triumph in the twentieth century, survived in Justice Harlan's dissent. The case of Robertson v. Baldwin arose when several merchant mariners were arrested for deserting their ship in Oregon in breach of the contracts they had signed agreeing to perform the duties of seamen during the entire voyage. The men were arrested and held until the ship was ready to sail, and then they were placed on board against their wills. They refused to perform their duties, and when the ship returned to San Francisco they were arrested and charged with refusing to work in violation of a federal statute governing merchant seamen. They sued based on a writ of habeas corpus, asking that they be freed from their confinement, and argued that the federal statute under which they were being held violated the involuntary servitude provision of the Thirteenth Amendment. ${ }^{27}$

The court upheld the validity of the statute on two grounds. The first, broader ground is the more interesting one. The validity of this statute, Justice Brown wrote for the court,

depends upon the construction to be given to the term "involuntary servitude." Does the epithet "involuntary" attach to the word "servitude" continuously, and make illegal 
any service which becomes involuntary at any time during its existence; or does it attach only at the inception of the servitude, and characterize it as unlawful because unlawfully entered into? If the former be the true construction, then, no one, not even a soldier, sailor or apprentice, can surrender his liberty, even for a day; and the soldier may desert his regiment upon the eve of battle, or the sailor abandon his ship at any intermediate port or landing, or even in a storm at sea.... If the latter, then an individual may, for a valuable consideration, contract for the surrender of his personal liberty for a definite time and for a recognized purpose, and subordinate his going and coming to the will of another during the continuance of the contract; - not that all such contracts would be lawful, but that a servitude which was knowingly and willingly entered into could not be termed involuntary. Thus, if one should agree, for a yearly wage, to serve another in a particular capacity during his life, and never to leave his estate without his consent, the contract might not be enforceable for the want of a legal remedy, or might be void upon grounds of public policy, but the servitude could not be properly termed involuntary. Such agreements for a limited personal servitude at one time were very common in England [citing the 1823 English statute]... . The breach of a contract for personal service has not, however, been recognized in this country as involving a liability to criminal punishment, except in the case of soldiers, sailors and possibly some others, nor would public opinion tolerate a statute to that effect. ${ }^{28}$

The majority correctly saw that criminal punishment for labor-contract breaches was not nearly so anomalous as many people in the United States thought. It used English practice of the period as a way of vindicating its choice of freedom of contract over freedom of person, its resolution of that irresolvable dilemma within liberalism itself. The court's second ground was based on the opinion that "the [Thirteenth] amendment was not intended to introduce any novel doctrine with respect to certain descriptions of service which have always been treated as exceptional," merchant mariners constituting one of these exceptions. ${ }^{29}$ In a blistering dissent, Justice Harlan offered this reply to the court's opinion: "The condition of one who contracts to render personal services in connection with the private business of another becomes a condition of involuntary servitude from the moment he is compelled against his will to continue in such service.... [T] o require him, against his will, to continue in the personal service of his master is to place him and keep him in a condition of involuntary servitude." ${ }^{30}$ Harlan opined that

If congress under its power to regulate commerce with foreign nations and among the several states, can authorize the arrest of seamen who engaged to serve upon a private vessel, and compel him by force to return to the vessel and remain during the term for which he engaged, a similar rule may be prescribed as to employés 
upon railroads and steamboats engaged in commerce among the states. ... Again, as the legislatures of the States have all legislative power not prohibited to them ... why may not the States, under the principles this day announced, compel all employés of railroads engaged in domestic commerce, and all domestic servants, and all employés in private establishments, within their respective limits, to remain with their employers during the terms for which they were severally engaged, under penalty of being arrested by some sheriff or constable, and forcibly returned to the service of their employers? ${ }^{31}$

Harlan, a Southerner himself, may well have realized that the majority's opinion could open the floodgates to this kind of legislation in the South. Immediately following the Civil War a number of Southern states had attempted to enact black codes that contained provisions, among others, for the criminal punishment of labor contract breaches. These were characterized in the North as attempts to reimpose slavery, and most of the codes were repealed or withdrawn, though some of these early laws survived. ${ }^{32}$ With one eye on possible Northern reaction, in the 1880 s Southerners began to fashion a new set of laws calling for criminal punishment, now, in most cases, not directly for breach of labor contracts but for acceptance of advances followed by failure to work out one's time. These socalled false pretense statutes proliferated in the 1880s and 1890s and were mainly used to compel black farm workers to perform their labor agreements. In agriculture, a reliable labor force was especially important. Entire crops might be lost if workers were not available at crucial times in the growing season. To ensure a reliable labor force, Southern landowners in this period typically signed black farm workers to year-long contracts. On signing, a landowner would advance a sum of money to a worker as a loan repayable by deductions from wages during the term. Under these false pretense statutes, if a worker left before completing the contract term and while still in debt to the landowner, he could be criminally prosecuted for committing a species of fraud and fined or imprisoned. Technically these prosecutions were for fraud and not for breach of a labor agreement, but in reality the statutes made it possible for landowners criminally to enforce the labor agreements of their black agricultural workers.

Under the logic of Robertson v. Baldwin, however, such subtlety would not be necessary. Southerners could feel free to attack the problem of labor contract enforcement directly. ${ }^{33}$ Indeed, the majority's opinion echoed an

31 Ibid., 302-3.

32 William Cohen, At Freedom's Edge: Black Mobility and the Southern White Quest for Racial Control, 1861-1915 (Baton Rouge, La., 1991), 28-37.

33 A number of Southern legislatures enacted these statutes as false pretense statutes in order to circumvent state constitutional restrictions on imprisonment for debt. 
opinion delivered by the South Carolina Supreme Court not too many years earlier in State v. Williams, ruling that a South Carolina statute that provided directly for the criminal punishment of labor contract breaches did not violate the constitution's prohibition of involuntary servitude.

If the general assembly sees proper to make the violation of a particular species of civil contracts a criminal offence, we are unable to discover in the provisions of the constitution anything which forbids such legislation. No person is required to enter into such a contract unless he chooses to do so; and if he does so, he must take the consequences affixed by the law to the violation of a contract into which he has voluntarily entered. ... We are unable to discover any feature of "involuntary servitude" in the matter. Everyone who undertakes to serve another in any capacity parts for a time with that absolute liberty which it is claimed that the constitution secures to all; but as he does this voluntarily, it cannot be properly said that he is deprived of any of his constitutional rights; and if he violates his undertaking he thereby of his own accord subjects himself to such punishment as the law making power may have seen fit to impose for such violation. ${ }^{34}$

The opinions in Robertson v. Baldwin and State v. Williams make apparent that the interpretive tradition developed in Illinois in the 1820 s still possessed great vitality at the close of the nineteenth century, long after the Civil War. At the time Robertson v. Baldwin was decided in 1897 there were, in effect, two systems of contract law covering labor agreements in this country: The Southern one bore rough similarities to the contract system in effect in Prussia and England not too many years before. The Northern one, in which neither specific performance nor penal sanctions were available for labor contract breaches, had a long history and was supported by its own constitutional tradition that harkened back to a decision of the Indiana high court. Under these two constitutional traditions, both systems could make plausible arguments that they were free labor systems based on free contract.

The truth seems to have been that the majority in Robertson v. Baldwin did not believe their decision applied beyond the situation of merchant mariners. This is interesting in and of itself, given that Robertson v. Baldwin was brought before the Supreme Court as a test case mounted by the seamen's union. ${ }^{35}$ The decision produced a strong reaction among organized seamen. As the San Francisco Examiner put it: "According to the highest tribunal which can pass on the matter, the difference between a deep-water sailor and a slave is $\$ 15$ per month." ${ }^{36}$ Union leaders immedi-

35 Hyman Weintraub, Andrew Furuseth, Emancipator of the Seamen (Berkeley, Calif., 1959), 35.

36 Quoted in ibid. 
ately launched a campaign in Congress to have the federal statute amended. Under intense pressure from the seamen's union, Congress did give the seamen half of what they had been lobbying for, amending the statute, but only eliminating criminal penalties for desertion in American ports; it retained criminal penalties for desertion in foreign ports. ${ }^{37}$ The seamen's union continued to lobby Congress on and off for another decade before ultimately achieving its goal of having penal sanctions for breach of contract abolished. It was not until 1915 with the LaFollette Seamen's Act that Congress finally eliminated criminal penalties for desertion from private vessels. ${ }^{38}$ By this time the seamen's victory was primarily symbolic, however, for shipowners had long since ceased to use penal sanctions to enforce the contracts of their sailors.

The seamen's union had continued to pursue its goal of eliminating penal sanctions for breach of contract even after the Supreme Court had begun to hand down its first peonage decisions. In Clyatt v. United States (1905), decided only eight years after Robertson, the court finally made a definitive choice between constitutional traditions, adopting the Indiana interpretation of the term "involuntary servitude." Justice David J. Brewer writing for the court, declared

Peonage is sometimes classified as voluntary or involuntary, but this implies simply a difference in the mode of origin, but none in the character of the servitude. The one exists where the debtor voluntarily contracts to enter the service of his creditor. The other is forced upon the debtor by some provision of law. But peonage, however created, is compulsory service, involuntary servitude. . . A clear distinction exists between peonage and the voluntary performance of labor or rendering of services in payment of a debt. In the latter case the debtor, though contracting to pay his indebtedness by labor or service, and subject like any other contractor to an action for damages for the breach of contract, can elect at any time to break it, and no law or force compels performance or a continuance of the service. ${ }^{39}$

Although it implicitly rejected the view of the Robertson majority, the Clyatt court did not explicitly overrule Robertson. Rather, it limited the earlier case to its facts, characterizing the second ground for the decision as the rule of the case, and then it simply brushed the case aside. "We need not stop to consider," Brewer wrote, "any possible limits or exceptional cases, such as the service of a sailor [citing Robertson v. Baldwin]." ${ }^{40}$ In Bailey v. Alabama, decided in 1911, the Supreme Court struck down Alabama's

39 Clyatt v. United States, 197 U.S. 207 (1905), 215.

40 Ibid., 216. 
false pretenses statute as a violation of the Anti-Peonage Act and the Thirteenth Amendment. Justice Charles E. Hughes, building on the Clyatt opinion, declared that the Anti-Peonage Act "necessarily embraces all legislation which seeks to compel the service or labor by making it a crime to refuse or fail to perform it." 41

Evidently, Northern elites were of two minds on the question of penal sanctions for breaches of labor contracts. When it came to their use against helpless black people in the South, with its history of slavery but also with its distance from Northern labor relations, Northern elites felt inclined to invoke the Indiana tradition that had, after all, first been developed in a similar context. The peonage cases that found their way before the Supreme Court had been initiated by federal authorities and did not grow out of an indigenous movement of black workers. The people responsible for the attack on Southern peonage were Progressives, committed to protecting the weak by reforming government and the legal system.

However, when the question of penal sanctions was posed outside the context of Southern labor relations as an abstract matter of contract law, or in the Northern context where many white workers were organized, possessed suffrage, and where what penal sanctions there were applied only to a tiny portion of the working population, the question seems to have presented greater difficulties for the elites. Not only do we have the decision in Robertson to point to, but during the first decade of the twentieth century the legislatures of three Northern states made their sympathy with Robertson clear when they enacted false pretenses labor contract statutes of their own. These statutes aimed at enforcing the labor agreements of white workers who had received transportation advances to remote lumbering, mining, or railroad construction sites. Minnesota enacted such a statute in $1901,{ }^{42}$ followed by Michigan in $1903,{ }^{43}$ and Maine in $1907 .{ }^{44}$ We do know that the Maine statute was enforced. Fifty or sixty cases were brought before one rural justice of the peace after $1907 .^{45}$

In his dissent in Bailey, Oliver Wendell Holmes suggested that the majority's opinion had been improperly swayed by the particular social context in which the case had arisen. "We all agree that this case is to be considered and decided in the same way as if it arose in Idaho or New York. Neither public document nor evidence discloses a law which by its

41 Bailey v. Alabama, 219 U.S. 219 (1911), 243.

42 General Laws of Minnesota for 1901, chap. 165, pp. 212-13.

43 Michigan Compiled Laws, \$S 408.582-408.583.

44 The Revised Statutes of Maine (1917), chap. 128, $\$ 12$.

45 John Clifton Elder, "Peonage in Maine," A Manuscript Report sent to the Attorney General of U.S., National Archives, Record Group \#60 Dept. of Justice file \#50-34-0, p. 13. 
administration is made something different from what it appears on its face, and therefore the fact that in Alabama it mainly concerns the blacks does not matter." ${ }^{46}$ He went on to explain how deeply problematic the majority's opinion was. "The Thirteenth Amendment," Holmes wrote,

does not outlaw contracts for labor. That would be at least as great a misfortune for the laborer as for the man that employed him. For it certainly would affect the terms of the bargain unfavorably for the laboring man if it were understood that the employer could do nothing in case the laborer saw fit to break his word. But any legal liability for breach of contract is a disagreeable consequence which tends to make the contractor do as he said he would. Liability to an action for damages has that tendency as well as a fine. If the mere imposition of such consequences as tend to make a man keep to his promise is the creation of peonage when the contract happens to be for labor, I do not see why the allowance of a civil action is not, as well as an indictment ending in a fine.... I do not blink the fact that the liability to imprisonment may work as a motive when a fine without it would not, and that it may induce the laborer to keep on when he would like to leave. But it does not strike me as an objection to a law that it is effective. If the contract is one that ought not to be made, prohibit it. But if it is a perfectly fair and proper contract, I can see no reason why the State should not throw its weight on the side of performance. ${ }^{47}$

Holmes was right, of course, that all contract remedies operate to enforce agreements by presenting the breaching party with a choice between performing and a disagreeable alternative. To the extent that a party decides to perform labor in order to avoid the unpleasant alternative, that party may be said to have chosen the lesser evil voluntarily, or to have chosen it under coercion. Either characterization is available, but once we decide to characterize such a choice as coerced, as the majority in Bailey did with respect to criminal penalties, then there is no logical ground for saying that any similar choice is "voluntary." We must conclude that labor contracts cannot be enforced through any legal remedy at all consistent with the prohibition against involuntary servitude.

Although Holmes was correct about all this, it did not seem to have bothered the majority in either Clyatt or Bailey, both of whom blithely ignored the coercive effects of money damages for contract breaches, presenting them, in fact, as the opposite of "compelled" performance. "A clear distinction exists," Justice Brewer wrote in Clyatt, "between peonage and the voluntary performance of labor or rendering of services in payment of a debt. In the latter case the debtor, though contracting to pay his indebtedness by labor or service, and subject like any other contractor to an action for damages 
for breach of that contract, can elect at any time to break it, and no law or force compels performance or a continuance of the service." 48

It is also true, as Holmes recognized, that certain alternatives to performance are less unpleasant than others, and fewer people will tend to choose performance when confronted with them. But the performance of those who choose to avoid these unpleasant alternatives by rendering the labor service is no more voluntary than the labor service of those who choose to perform to avoid the unpleasant alternative of prison. The decision of the majority is, from a logical standpoint, arbitrary, a decision to draw a line through a continuum and to call certain decisions to perform labor under certain kinds of threats "voluntary" and other decisions to perform labor under other kinds of threats "involuntary." In fact, the decision as to where to draw such a line is not a decision about where coercion begins or ends in labor relations, but rather a normative and political decision about what kinds of hard choices we should continue to allow certain people to force others to make and what kinds we should not permit.

There is no natural or logical point in this process. The peonage cases place criminal penalties for breaches of labor contracts on one side of the line and ordinary money damages on the other, without any explanation or justification for this particular position.

In the peonage cases, the Supreme Court created the modern constitutional standard for free labor by rejecting an earlier constitutional tradition that had defined free labor differently. This decision was forced on the court by the perceived need to combat Southern efforts to reimpose a form of servitude on black people. And it is to this moral and political decision that we must trace the constitutional origins of modern free labor in this country, just as we must trace the origins of modern free labor in England to a political and moral victory of the laboring classes.

Modern free labor did not arise as the result of the spread of liberal ideas or the diffusion of free markets based on free contract. It was the result of a difficult political and moral resolution of fundamental dilemmas within liberalism itself. Liberalism demanded that market transactions be voluntary, not coerced. But liberal ideas provided no objective, value-neutral means for distinguishing coerced from voluntary decisions. Only changing political, constitutional, and moral circumstances in the last quarter of the nineteenth century produced the modern definition of coerced labor that included within that definition voluntary contractual labor enforced through specific performance or penal sanctions. Once an arbitrary line 
had been drawn through a continuum of contract remedies, it became possible to identify coerced contractual labor with contractual slavery. This expansion of the definition of contract of slavery made more justifiable a restriction on the freedom to contract into such relationships.

Most nineteenth-century liberals had long since resolved the conflict between freedom of contract and freedom of person in favor of freedom of person when it came to contracts of slavery. Most took the position that individuals should not be free to alienate their freedom. Once contractual labor enforced through penal sanctions came to be redefined as a form of slavery, the same resolution of this basic liberal dilemma could be adopted in the case of such contracts. Modern free labor is not the result of a regime of perfect freedom of contract, but is the product of restraints placed on freedom of contract in the interest of preserving liberty of person. ${ }^{49}$ It represents a particular resolution of fundamental dilemmas within liberalism itself. Other resolutions of these basic problems were possible, leading to regimes of free contract like those in place in England, Prussia, and Illinois during the first two-thirds of the nineteenth century. It was only a set of contingent political events and changing moral standards that produced the modern version of free labor during the late nineteenth and early twentieth centuries. ${ }^{50}$

49 See Binder, "Substantive Liberty," and Knight, Freedom \& Reform.

50 Ibid. 